\title{
Standa tannplantar náttúrulegum tönnum framar?
}
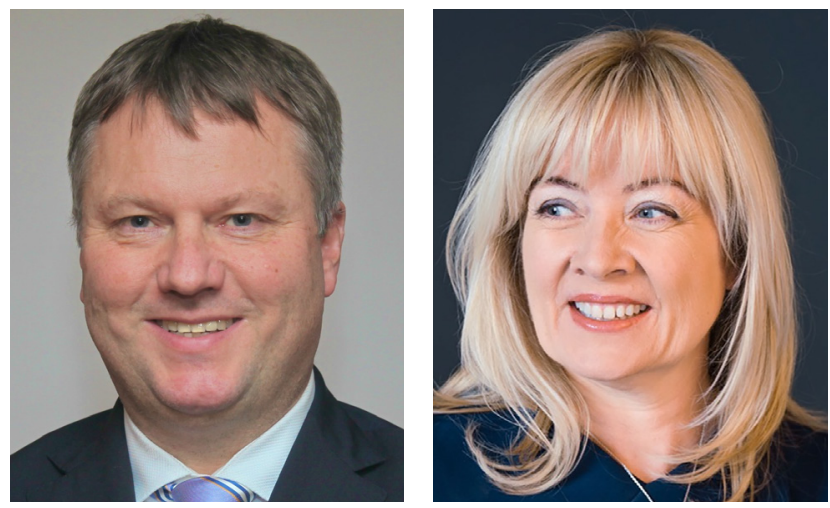

\author{
BJARNI ELVAR PJETURSSON, DOKTOR ODONT, DR. MED. DENT, MAS PERIO \\ PRÓFESSOR Í MUNN- OG TANNGERVALAEKNINGUM, TANNLAEKNADEILD HÁSKÓLA ÍSLANDS \\ KRISTÍN HEIMISDÓTTIR, CAND. ODONT, SÉRFRAEĐINGUR Í TANNRÉTTINGUM \\ LEKTOR Í TANNRÉTTINGUM, TANNLAEKNADEILD HÁSKÓLA ÍSLANDS
}

NETFÖNG: BEP@HI.IS, KRISTINHE@HI.IS TANNLAEKNABLAĐIĐ 2019; 37: 38-45

doi: 10.33112/tann.37.1.4

\section{ÁGRIP}

Alnetið býr yfir miklum fróðleik af ýmsum toga. Par úir og grúir af upplýsingum um tannplanta, en upplýsingar um tennur eru af skornum skammti. Í pessari grein eru bornar saman lifunarhorfur tannplanta við lifunarhorfur náttúrulegra tanna og áhrifapættir ræddir. Til einföldunar er umræðan byggð á hefðbundinni flokkun tanna í öruggar, vafasamar og vonlausar. Öruggar tennur ættu að endast vel og lengi án mikillar meðferðarbarfar. Vafasamar tennur gætu purft á talsverðri meðferð að halda og stöðugu eftirlit. Eina meðferð sem skynsamleg er fyrir vonlausar tennur, er úrdráttur. Margvíslegir áhættupættir geta aukið líkur á pví að vafasöm tönn lendi sem vonlaus tönn og sé fjarlægð. Rétt er að benda á að tannplantar eiga sér aldrei betri horfur en heil og heilbrigð tönn. Tannplantar og plantaborin tanngervi eru afbragðskostir til að bæta fyrir tapaðar tennur, en eiga aldrei að koma í stað heilbrigðra, náttúrulegra tanna.

Lykilorð: Tennur, tannplantar, lifunarhorfur, meðferðaráætlun, áhættugreining einstakra tanna.

Í erli dagsins parf tannlæknir að taka ótal ákvarðanir á skömmum tíma varðandi meðferð sjúklinga. Pegar tennur eru illa farnar eða hluti peirra tapaðar, er meðferðarkostur oft að setja tannplanta í stað peirra tanna sem vantar og byggja tann- og/eða munngervi ofan á pá og pær tennur sem til staðar eru (1). Meðferðin byggir yfirleitt á peirri pekkingu sem tannlæknir öðlast í grunnnámi tannlæknisfræðinnar ásamt símenntun og reynslu í starfi.

Í grunnámi í tannlæknisfræði læra nemendur að vandamál tanna geti verið ýmis konar: Tennur geta skemmst (2-4) og skemmdin getur náð inn í kviku með peim afleiðingum að kvikuvefur deyr (2-5). Tönn getur brotnað eða tapað festu vegna tannhaldssjúkdóma $(2,6,7)$. Ef gert er við tönn eða sett á hana króna, geta einnig komið vandamál út frá viðgerðinni (2). Hvað varðar tannplanta, pá hafa rannsóknir fyrst og fremst beinst að pví hversu lengi tannplantar hafa beinfestu án pess að brotna, en minna hefur farið fyrir rannsóknum sem lúta að peim líffræðilegu og tæknilegu vandamálum sem fylgt geta tannplantanum sjálfum og pví tanngervi sem hann ber. Pví er auðvelt að álykta að viðgerðum tönnum fylgi ýmis vandamál en tannplöntum nánast engin (8-12). 


\section{Horfur tanna}

Fyrir nokkrum árum rannsökuðu Schätzle og félagar bólgu í tannhaldi sem áhrifavald varðandi lifunarhorfur tanna. Rannsóknin byggðist á gögnum frá Löe, Anerud og Boysen sem höfðu skoðað tennur norskra karlmanna á 3-7 ára fresti i 26 ár. Ástand tannhalds var greint eftir Löe og Silness kvarðanum (13) á eftirfarandi hátt (14):

Hópur 1: Engin blæðing úr tannhaldi p.e. algjörlega

heilbrigt ástand tannar öll skipti sem hún var skoðuð (GI 0-1).

Hópur 2: Af og til blæðing á pessu 26 ára tímabili (GI 1-2).

Hópur 3: Blæðing úr tannhaldi p.e. stöðug tannhaldsbólga í öll pau skipti sem hún var skoðuð (GI 2).

Höfundar reiknuðu út lifunarhorfur tanna út frá pessum mælingum og gildum. Hópar 1 og 2 voru með 100\% lifunarhorfur til 10 ára og í priðja hópi 99\% til tíu ára. pegar horfur til 50 ára voru reiknaðar út frá niðurstöðunum kom í ljós að hópur 1 var með 99.5\% lifunarhorfur og hópur 2 með 93.8\%, sem einnig telst allgott. Síga tók á ógæfuhlið í priðja hópi, par sem tannhaldsbólgur voru alltaf til staðar. Par voru 50 ára horfur einungis 63,4\% (13). Pví er hægt að draga pá ályktun að heilbrigðar tennur án bólgu eða sýkingar í tannhaldi geta enst svo áratugum skipti án vandamála.

\section{Horfur tannplanta}

Ein fyrsta yfirlitsrannsókn sem skoðaði ekki einungis lifunarhorfur tannplanta heldur einnig líffræðileg og tæknileg vandamál sem peim geta fylgt var birt af Berglund og félögum árið 2002 (15). Par voru metnar framsæknar langtímarannsóknir par sem tannplöntum var fylgt eftir í a.m.k. 5 ár. Peir komust að pví að lifunarhorfur tannplanta, sem studdu úrtakanleg munngervi, til 5 ára væru 92\% og horfur tannplanta sem báru föst tanngervi væru 95\% (15). pó að pessar tölur séu nokkuð háar á skalanum 1-100, pýða 92\% lifunarhorfur að $8 \%$ tannplanta tapast á 5 árum, sem er einn af hverjum 12 tannplöntum. Ef horfur aukast i 95\% tapast einn planti af hverjum 20 á fimm ára tímabili. pað skiptir pví verulegu máli fyrir tannlækni og sjúkling hvort horfur séu 90\% eða 99\%. Pað pýðir í raun að tífalt fleiri plantar tapast á tímabilinu séu horfur aðeins 90\%.

Nýlegar samantektarrannsóknir og meta-analýsur (1-5) sýna að reikna má með að 2-3\% tannplanta tapast á græðslutíma. Árleg afföll tannplanta sem pegar hefur verið smíðað á, eru áætluð 0.3-1.3\%, sem gefa 95.2\% lifunarhorfur planta til 10 ára sem bera stakar plantakrónur (12), 93,1\% fyrir planta með föstum fjölliða tanngervum (11) en einungis $82,1 \%$ fyrir planta sem bera blönduð föst tanngervi, á planta og tennur (9).

Samanburður tannplanta og tanna er pví verulega óhagstæður plöntum. Pví er við að bæta að ekki eru til rannsóknir sem meta lifunarhorfur tannplanta til margra áratuga, en slíkar rannsóknir eru til á tönnum.

\section{Áhrifapættir}

pegar metnar eru lifunarhorfur tannplanta parf að líta til nokkurra pátta. Sjúklingar sem taka pátt í rannsóknum, endurspegla ekki endilega hið almenna pýði vegna útilokandi pátta rannsókna. Sem dæmi útiloka margar rannsóknir reykingafólk, sjúklinga með sykursýki, sjúklinga með tannhaldssjúkdóma, ósamvinnupýða sjúklinga, sjúklinga með slæma munnhirðu, sjúklinga með takmarkaðan beinstuðning og einnig hafa sjúklingar með sögu um gnístur eða aðra ofvirkni tyggingarvöðva verið útilokaðir. Pó eru petta oft peir sem purfa á tannplöntum að halda vegna tanntaps.

Vert er að geta að yfir 1000 tannplantakerfi hafa verið próuð og notuð síðustu áratugi. Flest peirra eru pví miður án bakgrunnsrannsókna og erfitt að bera saman langtíma árangur mismunandi tegunda par sem langtímarannsóknir hafa aðeins verið birtar fyrir örfá tannplantakerfi. Erfitt getur verið að halda fram að ein tegund hrjúfs yfirborðs sé betri en önnur (16). Karoussis og félagar (17) gerðu áhugaverða rannsókn, par sem skoðuð voru áhrif plantaforms á horfur tannplanta. Rannsóknin tók 10 ár og var framsækin. 89 sjúklingar fengu mismunandi gerðir tannplanta - annars vegar 112 hola skrúfulaga planta og hins vegar 49 hola sílindralaga planta. Báđar tegundir voru úr sama efni, frá sama framleiðanda, með sama háls, yfirborð og pvermál. Eini munur var lögunin (Mynd 1). Báðar tegundir voru holar, sem leyfði beini að vaxa ekki aðeins að plantanum utanverðum heldur einnig inn í hann. Skrúfulaga plantinn var með aukagengjur umfram sílindralaga plantann, ætlað til að auka stöðugleika á græðslutíma.

Pessum sjúklingum var fylgt eftir í 10 ár. Eftir 5 ár var enginn munur á horfum pessara tannplanta. Eftir 10 ár kom hins vegar í ljós að talsvert fleiri sílindralaga tannplantar höfðu tapast (14,3\% vs. 4,6\%) miðað við skrúfulaga tannplanta með gengjunum (17). Til að setja petta í klíniskt samhengi pá tapaðist einn af hverjum sjö sílindralaga plöntum á móti einum af hverjum 22 skrúfulaga 


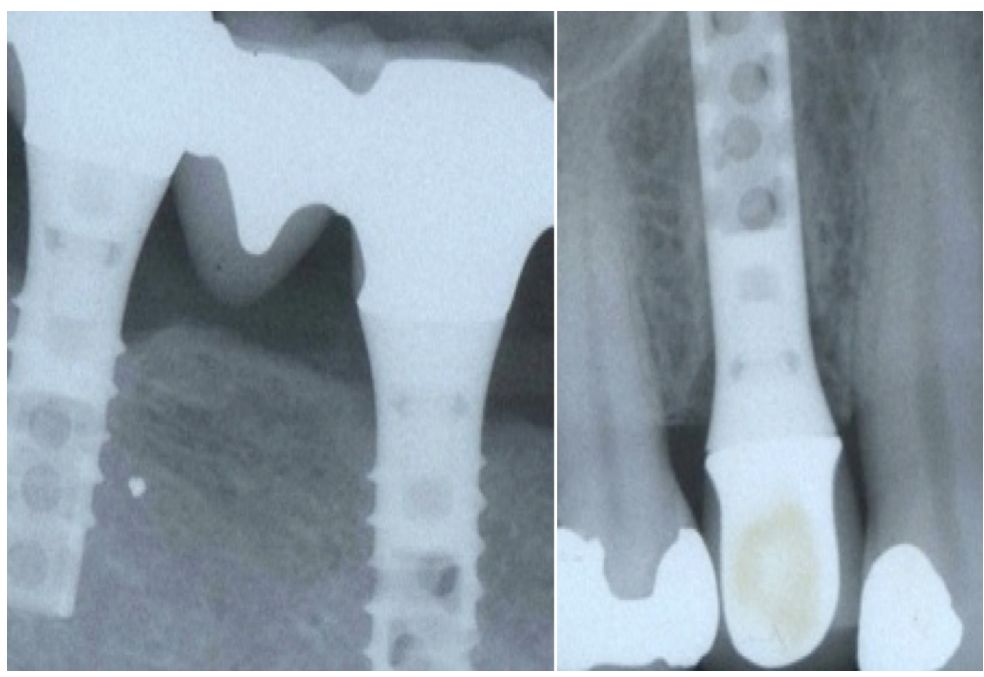

Mynd 1. Röntgenmynd sem sýnir annarsvegar holan cílindralagaðan tannplanta (hægri) og hinsvegar holan skrúfulaga tannplanta (vinstri).

plöntum. Draga má pá ályktun að gengjur í skrúfulaga plantanum hafi gert gæfumun varðandi horfur, en pessi klíníski mikilvægi munur kom bví miður ekki í ljós fyrr en eftir 7-9 ár. Petta er mikilvægt að hafa í huga pegar rannsóknir eru skoðaðar varðandi horfur tannplanta, pví flestar ná ekki yfir nema 5 ára tímabil. Einnig verður að hafa í huga að tannplanti sem tollir í munni telst vel heppnuð aðgerð í rannsóknum, en oft er ekki litið til annarra pátta eins og líffræðilegra og/eða tæknilegra vandamála.

\section{Árangur (e. Success) tannplanta}

Ekki er nægilegt að meta lifunarhorfur tannplanta, heldur er mikilvægt að skoða einnig vandamál eða fylgikvilla (e. complications). Kerfisbundin yfirlitsgrein (8) sem mat horfur tannplanta, skoðaði einnig fylgikvilla planta og tanngerva sem verið höfðu í munni i 5 ár hið minnsta. Árangur var skilgreindur svo að sjúklingurinn væri án allra fylgikvilla eða vandamála á tímabilinu. Rannsóknin sýndi fram á að af tannplantabornum tanngervum, voru einungis $61,3 \%$ án allra líffræðilegra og/eða tæknilegra fylgikvilla. Höfundar drógu pá ályktun að prátt fyrir að lifunarhorfur væru góðar, væri sjúklingur ekki endilega án vandamála. Í pví samhengi má nefna rannsókn, sem gerð var við tannlæknadeildina í Bern í Sviss par sem skoðaðir voru sjúklingar sem höfu verið með tannplanta og föst tanngervi i 10 ár að meðaltali (18). I l ljós kom að horfur voru mjög góðar, einungis 2.5\% af tanngervunum tapaðist, en í ofanálag purftu 16,8\% af tanngervunum á einhverjum lagfæringum að halda vegna líffræðilegra og/eða tæknilegra örðugleika.
Skipta má vandamálum í:

a. Líffræðileg vandamál eins og los, festutap, mjúkvefjavandamál og peri-implantitis.

b. tæknilega vandamál eins og brot tannplanta, los eða brot á skrúfu eða abutmenti, brot á málmeða keramikgrind og brot á ábrenndu postulíni. c. Útlitsvandamál.

Pessi flokkun er pó ekki alveg skýr, par sem mörg vandamál má rekja til samspils tæknilegra, líffræðilegra og útlitslegra pátta. Pjetursson og félagar (19) skoðuðu hvort breytingar hefðu orðið á tíðni vandamála síðustu ár borið saman við árdaga tannplantafræði. Horfur og tíðni fylgikvilla voru bornar saman í eldri (fyrir árið 2000) og nýrri rannsóknum (eftir árið 2000). Í ljós kom, eins og sést í Töflu 1, að mikil framför hefur átt sér stað prátt fyrir að tíðni líffræðilegra og tæknilegra vandamála sé enn of há. Mikilvægt er að greina orsök vandamála til að geta fyrirbyggt pau í framtíðinni (19). Ekki má heldur líta fram hjá pví að hlutdrægni getur gætt í rannsóknum peim sem skoðaðar voru. Miklir fjárhagslegir hagsmunir eru í húfi fyrir tannplantaframleiðendur sem oft styrkja rannsóknir af pessu tagi. par hafa einnig átt sér miklar umbætur, pví gæði og eftirlit rannsókna hefur aukist verulega á síðastliðnum árum og í dag fást rannsóknir ekki birtar í virtustu vísindatímaritunum nema vel sé vandað til verka og nútíma verkferlum fylgt.

\begin{tabular}{|l|c|c|}
\hline Tegund vandamáls: & $\begin{array}{c}\text { Stakar } \\
\text { krónur } \\
\text { á planta (\%) }\end{array}$ & $\begin{array}{c}\text { Föst } \\
\text { fjöleininga } \\
\text { tanngervi á } \\
\text { planta (\%) }\end{array}$ \\
\hline Útlits vandamál & 5,4 & ekki skráð \\
\hline Líffræðileg vandamál & 6,4 & 9,4 \\
\hline Beintap meira en 2mm & 6,3 & 2,5 \\
\hline Los á skrúfu og/eða abutmenti & 5,6 & 4 \\
\hline Retention tap & 3,1 & ekki skráð \\
\hline Brot á planta & 0,1 & 0,5 \\
\hline Brot á skrúfu og/eða abutmenti & 0,3 & 0,8 \\
\hline Brot á grind eða kjarna tanngervis & ekki skráð & 0,2 \\
\hline Brot á yfirborðs postulíni & 3,2 & 7,7 \\
\hline
\end{tabular}

Tafla 1. Yfirlit yfir útlitsleg, liffræðileg og tæknileg vandamál sem komið geta upp hjá stökum krónum og föstum fjölliða tanngervum á tannplanta fyrstu 5 árin í notkun - Einungis byggt á rannsóknum sem birtar eru eftir árið 2000. 


\section{Mýtur um tannplanta}

Í dag úir og grúir af upplýsingum á netinu um meðferðarkosti fyrir sjúklinga vegna tapaðra og skemmdra tanna. Ríkulegar upplýsingar er að finna um mismunandi tanngervi og tannplanta, par sem kostir peirra eru rómaðir. Skrautlegar lýsingar og ævintýraleg auglýsingamennska er ekki spöruð. par sem lítið fer fyrir svipuðum lýsingum varðandi náttúrulegar tennur, eiga pær oft undir högg að sækja í samanburði. Pví hafa tannlæknar og sjúklingar stundum fallið fyrir pessu skrumi og telja að meðferð með tannplönum sé betri kostur en að byggja á tönnum. Stundum virðist eins og tannlæknar hafi misst trú á náttúrulegum tönnum. Sjá má í kennslubókum, vísindagreinum og á ráđstefnum tilfelli par sem tennur, sem auðveldlega hefðu getað enst í mörg ár eða áratugi eru fjarlægðar til að skapa rými fyrir tannplanta. Skapast hafa mýtur varðandi tannhaldsmeðferð par sem talað eru um yfirmeðhöndlun tannhalds (e. periodontal overtreatment). Pessi hugmyndafræði gengur út á að úrdráttur tanna með smávægilegu festutapi sé skynsamlegri en hefðbundin tannhaldsmeðferð á peim forsendum að ísetning tannplanta sé auðveldari á fyrra stigi pegar beinfesta er meiri. Pessi söfnuður heldur pví fram að sé tannhald meðhöndlað og tönnum haldið lengur, aukist hætta á meira beintapi sem geri tannplantaísetningu erfiðari. Tannlæknar sem hafa pessa skoðun draga gjarnan tennur, sem auðvelt hefði verið að halda í mjög langan tíma, með reglulegri tannhaldsmeðferð og hreinsun (20).

Önnur mýta varðar úrdrátt allra eftirstandandi tanna (e. total extraction), séu einhverjar tennur pegar tapaðar eða vonlausar. Hugmyndin er að fyrirbyggja bólgur og beintap við tannplanta með pví að fjarlægja allar tennur. Fransson og félagar (21) skoðuðu sjúklinga og mátu beintap við planta. Skoðaðir voru 423 einstaklingar með 3.414 tannplanta sem verið höfðu í munnu í amk. 5 ár. Hjá $28 \%$ sjúklinganna voru einn eða fleiri tannplantar með verulegt beintap, sem var skilgreint beinatap niður á priðju gengju plantans. 12,4\% tannplanta voru greindir með slíkt beintap. Höfundar skiptu sjúklingunum í tvo hópa:

Hópur A: Einn eða fleiri tannplantar með beintap niður á priðju gengju eða meira.

Hópur B: Enginn tannplanti með verulegt beintap.

Ef kenningin um að úrdráttur allra tanna myndi fyrirbyggja festutap við tannplanta væri rétt, ættu fleiri einstaklingar án eigin tanna að vera í hópi B eða heilbrigða hópnum. Pví kom pað á óvart að peir sem voru án eigin tanna, voru hlutfallslega fleiri í hópi A, p.e. með beintap. Rannsóknin hnekkir pví peirri tilgátu að úrdráttur allra tanna fyrirbyggi bólgur og beintap við tannplanta (21).

Ef meirihluti tannlækna fer að trúa pví að tannplantar séu áreiðanlegri en náttúrulegar tennur og að miklu einfaldara væri að draga vafasamar tennur og setja tannplanta í staðinn pá myndi meðferð eins og rótfyllingar og tannhaldsmeðferð smám saman heyra sögunni til, ekki satt?

pví miður hefur tilkoma tannplanta gert suma tannlækna agressívari gagnvart náttúrulegum tönnum. Ađrir sjá tækifæri, að vera hófsamari og halda eigin tönnum til lengri tíma, en hafa tannplanta í bakhöndinni, ef tönn bregst.

\section{Meðferðaráætlun}

Aldrei verður ítrekað nóg að meðferðaráætlun flókinna tilfella skuli vera vönduð og byggð á gagnreyndum fræðum. Eftir að umkvörtunarefni sjúklings er greint og almenn heilsufars- og tannsaga tekin, parf að meta horfur hverrar einstakrar tannar. Taka parf mið af hversu mikið er eftir af tannvef (e. substance), ástandi tannhols og tannhalds. Flokka má tennur á einfaldan hátt sem öruggar, vafasamar eða vonlausar (Tafla 2):

Öruggar tennur geta enst vel án mikillar eða flókinnar meðferðar. Öruggar tennur eru pær sem hvorki eru vafasamar né vonlausar. Lögun kvikuhols skal leyfa hefðbundna rótfyllingu, burtséð frá pví hvort hennar sé pörf eða ekki.

Vafasamar tennur eru pær sem gætu purft á flókinni meðferð að halda og að auki viðhaldsmeðferð. Ekki er alltaf ljóst hvernig pessar tennur bregðast við meðferð

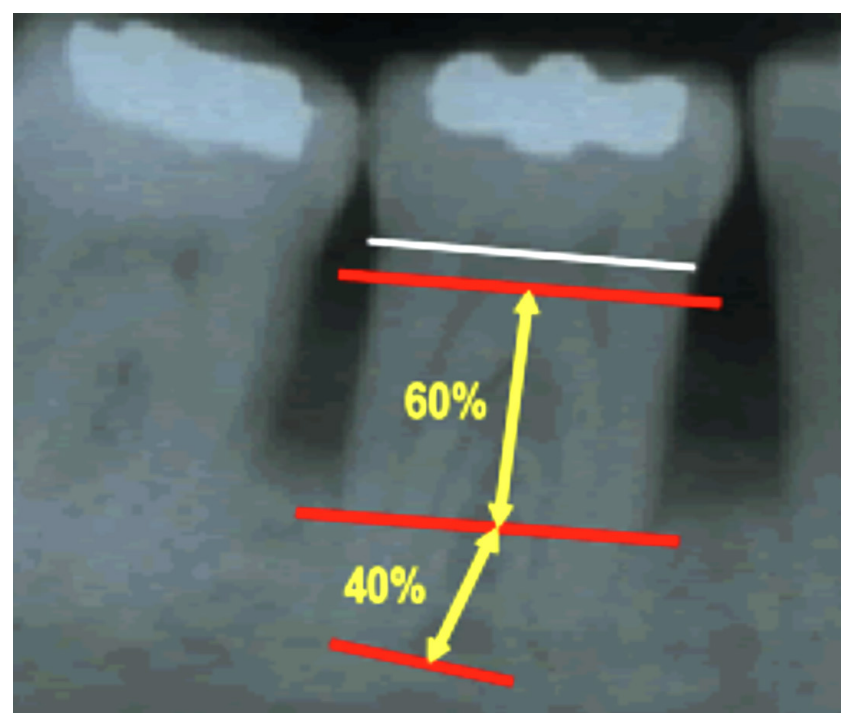

Mynd 2. Jaxl með u.p.b. 60\% festutap metið á röntgenmynd. Pessi tönn væri flokkuð vafasöm ef hún væri i fertugum einstaklingi, en örugg ef hún væri i áttræðum 
og pví getur verið skynsamlegt að forðast að nota pær sem brúarstólpa í tanngervi en láta pær heldur standa stakar. Tennur teljast vafasamar ef erfitt er að ná íhaldi (e. ferrule) í krónugerð, tennur með tannátu sem teygir sig niður á rót eða tennur með pykku stifti sem veikir styrk rótar, par sem verulegt magni af tannvef hefur verið fjarlægt. Tennur með rótarklofsvandmál klassa I , II eða III (22), tennur með lóðréttu beintapi og tennur sem hafa sýnilega á röntgenmynd misst beinfestu sem í prósentum er jöfn eða hærri en aldur sjúklings í árum talið (t.d. 50\% beintap hjá 50 ára gömlum einstaklingi) eru flokkaðar vafasamar (Mynd 2). Einnig tennur með lögun tannhols eða rótarganga sem gera rótfyllingu eða endurrótfyllingu erfiða, tennur með stóra umrótarbólgu (e. periapical lesion) og tennur sem purfa rótarendaaðgerð. Skiptir pá engu hvort tennur eru með einkenni eða einkennalausar.

Vonlausar tennur eru pær sem ekki er hægt að bjarga og úrdráttur eina leiðin. Tímasetning úrdráttar fer eftir ástandi tannar, einkennum eða sýkingum og er hluti af meðferðaráætlun. Dæmi eru tennur með tannátu i rótarklofi, endurtekna ígerð í tannhaldi, festutapi að rótarenda, umrótarbólgu út frá sýkingu i tannhaldi. Önnur dæmi eru tennur með lóđrétta sprungu i rót, láréttu pverbroti um miðbik rótar og endurrótfyllingar án árangurs (Tafla 2).
Pegar meðferðaráætlun er gerð, parf að ákveða með hvaða hætti á að byggja tanngervi i tannlaus bil. Til greina kemur að brúa bil með gerð tanngerva á tennur eða nota plantaborið tanngervi. Ef nota á náttúrulegar tennur sem stoðtennur, er ástand peirra metið áður en lokaákvörðun er tekin. Heilbrigðar óviðgerðar tennur eru ekki æskilegar stoðtennur. Heilbrigðar tennur, par sem synd væri að framkvæma tannskurð fyrir tanngervi og fjarlægja verulegt magn af heilbrigðum tannvef $(23,24)$. Ef aðliggjandi tennur við tannlaust bil falla í vafasama hópinn vegna ástands tannhalds, tannhols eða annarra áhættupátta, getur verið skynsamlegra að nota pær ekki sem stoðtennur. Ástand nágrannatanna leiðir oft til pess að meðferðarplanið verður tannplantaísetning og plantaborið tanngervi, par sem pær geta verið of "góðar" eða of "vafasamar" til að vera skysamlegur kostur sem stoðtennur.

Varðandi vafasamar tennur eru fjórir valkostir: Sá fyrsti að draga tönnina, annar að laga hana með einföldum hætti, t.d. með fyllingu, sá priðji er að byggja hana upp og krýna og að lokum að nota tönnina sem brúarstólpa fyrir fast tanngervi. Oft er skynsamlegast að halda slíkum tönnum stökum og binda pær ekki inni fjölliða tanngervi.

\begin{tabular}{|c|c|c|c|}
\hline & Tönn & Tannhald & Tannhol \\
\hline \multirow[t]{2}{*}{ Hópur I - öruggar tennur } & \multicolumn{3}{|c|}{ Tennur sem eiga að endast lengi, án umtalsverðrar meðferðar } \\
\hline & $\begin{array}{l}\text { Allar tennur sem eru hvorki } \\
\text { vafasamar né vonlausar }\end{array}$ & $\begin{array}{l}\text { Allar tennur sem eru hvorki } \\
\text { vafasamar né vonlausar }\end{array}$ & $\begin{array}{l}\text { Allar tennur sem eru hvorki } \\
\text { vafasamar né vonlausar }\end{array}$ \\
\hline \multirow[t]{2}{*}{ Hópur II - vafasamar tennur } & \multicolumn{3}{|c|}{$\begin{array}{l}\text { Tennur sem geta purft talsverða meðferð og viðhaldsmeðferð. Ekki er alltaf ljóst hvernig pessar tennur bregðast við } \\
\text { meðferð og pví betra að nota pær sem staka liði en hluta af stærri tanngervum. } \\
\text { Oft endast vafasamar tennur æfina á enda með réttri meðferð og samvinnu sjúkings }\end{array}$} \\
\hline & $\begin{array}{c}\text { Tennur sem hafa tapað svo miklum } \\
\text { tannvef að erfitt er að byggja pær } \\
\text { upp að nýju. Tennur með } \\
\text { rótarskemmd eða veikingu rótar } \\
\text { vegna taps á tannvef og breiðra } \\
\text { rótarstifta }\end{array}$ & $\begin{array}{l}\text { Tennur sem hafa tapað beini } \\
\text { (mælanlegt á röntgenmynd) sem er } \\
\text { jafn eða umfram lífaldur sjúklings. } \\
\text { Jaxlar með rótarklofsvandamál Kl. I, II } \\
\text { eða III. Tennur með lóðrétta beinpoka }\end{array}$ & $\begin{array}{c}\text { Tennur með krónuhol eða rótarganga } \\
\text { sem gera rótfyllingu eða } \\
\text { endurrótfyllingu erfiða, tennur með } \\
\text { stóra umrótarbólgu sem og tennur } \\
\text { sem purfa rótarendaaðgerð }\end{array}$ \\
\hline \multirow[t]{2}{*}{ Hópur III - vonlausar tennur } & \multicolumn{3}{|c|}{$\begin{array}{l}\text { Vonlausar tennur sem parf að draga úr. Tímasetning fer eftir ástandi tannar, einkennum, sýkingu og helgast af } \\
\text { meðferðaráætlun }\end{array}$} \\
\hline & $\begin{array}{l}\text { Tennur með skemmd í tannholi eða } \\
\text { rótarklofi }\end{array}$ & $\begin{array}{l}\text { Tennur með endurtekna ígerð í } \\
\text { tannhaldi, festutap niður undir } \\
\text { rótarenda eða tennur með } \\
\text { umrótarbólgu sem myndast hefur út } \\
\text { frá sýkingu í tannhaldi }\end{array}$ & $\begin{array}{c}\text { Tennur með lóðrétta sprungu í rót, } \\
\text { láréttu pverbroti um miðbik rótar eða } \\
\text { tennur par sem endurteknar } \\
\text { rótfyllingar hafa verið reyndar án } \\
\text { árangurs }\end{array}$ \\
\hline
\end{tabular}

Tafla 2. Yfirlitstafla um áhættugreiningu stakra tanna og hvaða pættir valda pví að pær eru flokkaðar sem öruggar, vafasamar eða vonlausar tennur. 


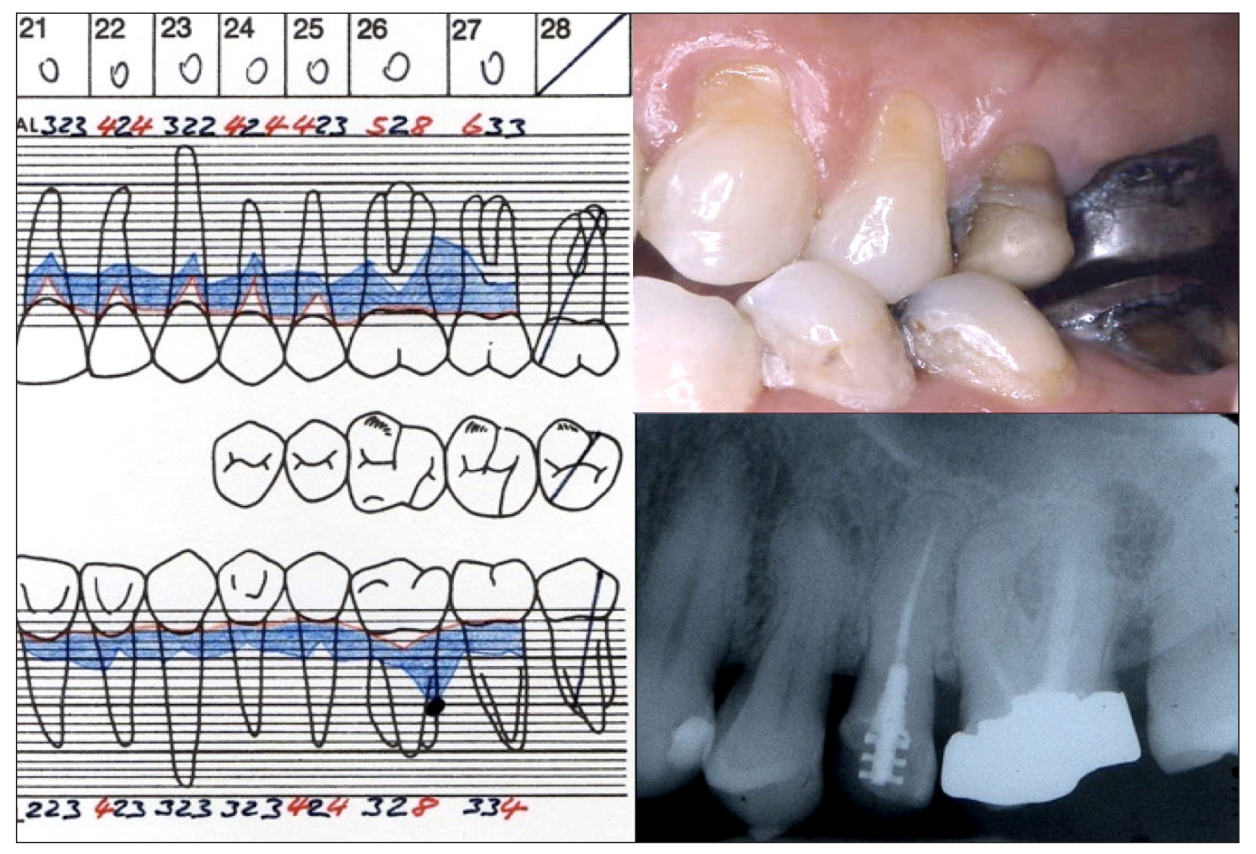

Mynd 3. Dæmi um vafasama tönn (26) með nokkra áhættupætti, rótareyðingu við palatal rót, tannskemmd mesialt, festutap og annarar gráđu rótarklofsvandamál distalt.

\section{Aðrir áhættupættir}

Séu fleiri en einn áhættupáttur vegna tannar til staðar, verður að leggja saman áhættuna til að meta heildarhorfur hennar. Ef tönn hefur $100 \%$ líkur að endast næstu tíu ár, pá fá lifunarhorfur hennar vægið 1.0. Ef tönn með $80 \%$ líkur á að endast í tíu ár, eru lifunarhorfur hennar 0.8. Ef fleiri en einn áhættupáttur er til staðar, minnka horfur hennar hlutfallslega. Sem dæmi má nefna tönn í 20\% áhættu að tapast næstu tíu ár vegna tannhaldssjúkdóma, auk $20 \%$ áhættu vegna tannholsvandamála, er heildaráhættan reiknuð með pví að margfalda 0.8 x 0.8 sem gerir 0.64 . pað pýðir að lifunarhorfur næstu tíu ár eru $64 \%$, eða að 36\% hætta á að tönnin tapist. Meðferðaráætlun yrði

\begin{tabular}{|l|c|}
\hline Margfaldir áhættubættir - dæmi: & \\
\hline Áhættupáttur tannar & $\%$ \\
\hline Tannskemmd & 3 \\
\hline Tannhald & 15 \\
\hline Rótfyllingar & 29 \\
\hline Stiftisuppbygging & 10 \\
\hline Enduruppbygging & 5 \\
\hline Líkur á 10 ára lifunarhorfum: & $53 \%$ \\
\hline
\end{tabular}

Tafla 3. Heildaráhætta tannar 26 á Mynd 3 metin á kerfisbundinn hátt. auðveldari ef hægt væri að greina áhættu hverrar tannar. Meta parf áhættu eins og tannátu, tannhaldssjúkdóma, tannholssjúkdóma, áhrif vegna stifta og uppbygginga. pannig er hægt að gera meðferðaáætlun á gagnreyndari hátt en verið hefur (Mynd 3 og Tafla 3).

\section{Tannplantar og tannhaldssjúkdómar}

Algengasta ástæða fyrir tanntapi fullorðinna er tannhaldssjúkdómar og beintap (25). Pví purfa margir tannhaldssjúklingar tannplanta. Pjetursson og félagar (26) skoðuðu árangur tannplantaísetningar 70 sjúklinga, sem höfðu tapað tönnum vegna tannhaldssjúkdóma. Pessi hópur fékk kerfisbundna tannhaldsmeðferð og í kjölfarið ígræðslu 165 tannplanta. Næstu ár voru 12 tannplantar til viðbótar græddir í vegna tapaðra tanna. Eftir að meðaltali 8 ár í viðhaldsmeðferð vegna tannhaldssjúkdóma var hópurinn rannsakaður sérstaklega og skipt í tvo hópa eftir ástandinu:

1. Allir tannplantar heilbrigðir og engin óeðlileg bólga við planta.

2. Einn eða fleiri tannplantar greindir með sýkingu eða bólgu (peri-implantitis).

pegar útkoma eftir 8 ár var skoðuð og borin saman við upphafsstöðu, kom í ljós að hópur með heilbrigða tannplanta (fyrri hópur) var með marktækt færri djúpa tannhaldspoka ( $\geq 5 \mathrm{~mm}$ ) eftir upphaflegu tannhaldsmeðferðina (meðaltal 
1.9) en hinn hópurinn var með marktækt fleiri djúpa tannhaldspoka (meðaltal 4.1) á sama tímapunkti. Af pessu er dregin sú ályktun að gæði tannhaldsmeðferðar hafði ekki einungis áhrif á tennur, heldur einnig heilbrigði mjúkvefs umhverfis tannplanta. Peir sem voru með fleiri tannhaldspoka að lokinni meðferð, voru einnig í meiri vandræðum með tannplanta. Ástand tannhalds á átta ára tímabilinu var stöðugt hjá fyrri hópi og meðaltal djúpra poka óbreytt eða 1.9 meðan sjúklingar með bólgu umhverfis tannplantana (e. peri-implantitis) mældust með marktækt fleiri djúpa poka átta árum eftir upphaflegu meðferð. Meðalfjöldi djúpra poka fór úr 4.1 i 6.4 á pessu tímabili. Pví virðist ástand tannhalds lúti sömu lögmálum við tennur og tannplanta og pví koma frekar upp vandamál og tannplantar tapist í sjúklingum sem eru með sýkingar og bólgur í tannhaldi (26).

\section{Niðurstaða}

Lifun og gagnsemi tannplanta verður aldrei umfram lifun og gagnsemi náttúrulegra, heilbrigðra og hreinna tanna. Tannplantar og föst tanngervi eru álitlegur og ákjósanlegur meðferðarmöguleiki par sem sjúkdómar og/eða áverki hefur haft neikvæðar afleiðingar í munnholinu, en peim fylgja oft líffræðileg og/eða tæknileg vandamál. Tannplantar eiga að koma í stað tapaðra tanna en aldrei skal fjarlægja nothæfar tennur í peim tilgangi að skapa rými fyrir tannplanta.

Grein pessi er byggð á grein höfunda: Dental implants - are they better than natural teeth? sem birtist í Eur J Oral Sci. 2018; 126 Suppl 1:81-87.

\section{Heimildir}

1. Pjetursson BE, Lang NP. Prosthetic treatment planning on the basis of scientific evidence. J Oral Rehabil 2008; 35: 72-79.

2. Ken T, Pjetursson BE, Lang NP, Chan ESY. Systematic review of the survival and complication rates of fixed partial dentures 2004; 15: 654-666.

3. Jokstad A, Mjör IA. Ten years' clinical evaluation of three luting cements. J Dent 1996; 24: 309-315.

4. Karlsson SA. Clinical evaluation of fixed bridges, 10 years following insertion. J Oral Rehabil 1986; 13: 423-432.

5. Bergenholtz G, Nyman S. Endodontic complications following periodontal and prosthetic treatment of patients with advanced periodontal disease. J Periodontol 1984; 55 : 63-68.

6. Sundh B, Odman P. A study of fixed prosthodontics performed at a university clinic 18 years after insertion. Int J Prosthodont 1997; 10: 513-519.

7. Valderhaug J. A 15 -year clinical evaluation of fixed prosthodontics. Acta Odontol Scand 1991; 49: 35-40.

8. Pjetursson BE, Tan K, Lang NP, Brägger U, Egger M, Zwahlen M. A systematic review of the survival and complication rates of fixed partial dentures (FDPs) after an observation period of at least 5 years $-\mathrm{I}$. Implant supported FDPs. Clin Oral Implants Res 2004; 15: 625-642.
9. Lang NP, Pjetursson BE, Tan K, Brägger U, Egger M, Zwahlen M. A systematic review of the survival and complication rates of fixed partial dentures (FDPs) after an observation period of at least 5 years II. Combined tooth- implant supported FDPs. Clin Oral Implants Res 2004; 15: 643-653.

10. Jung RE, Pjetursson BE, Glauser R, Zembic A, Zwahlen M, Lang NP. A systematic review of the survival and compli- cation rates of implant supported single crowns (SCs) after an observation period of at least 5 years. Clin Oral Implants Res 2008; 19: $119-130$.

11. Pjetursson $B E$, Thoma $D$, Jung $R$, Zwahlen $M$, Zembic A. A systematic review of the survival and complication rates of implant-supported fixed dental prostheses (FDPs) after a mean observation period of at least 5 years. Clin Oral Implants Res 2012; 23(Suppl 6): 22-38.

12. Jung RE, Zembic A, Pjetursson BE, Zwahlen M, Thoma DS. Systematic review of the survival rate and the incidence of biological, technical, and aesthetic complications of single crowns on implants reported in longitudinal studies with a mean follow-up of 5 years. Clin Oral Implants Res 2012; 23 (Suppl 6): 2-21.

13. Silness J, Löe H. Periodontal disease in pregnancy. Correlation between oral hygiene and periodontal condition. Acta Odontol Scand 1964; 22: 121-133.

14. Schätzle M, Loeh, Lang N P, Bürgin W, Anerud A, Boyesen $H$. The clinical course of chronic periodontitis. J Clin Periodontol 2004; 31: 1122-1127.

15. Berglundh T, Persson L, Klinge B. A systematic review of the incidence of biological and technical complications in implant dentistry reported in prospective longitudinal studies of at least 5 years. J Clin Periodontol 2002; 29: 197-212.

16. Derks J, Håkanson J, Wennström J, Tomasi C, Larsson M, Berglundh T. Effectiveness of implant therapy analyzed in a Swedish population: early and late implant loss. J Dent Res 2015; 94: 44-51.

17. Karoussis I, Brägger U, Salvi G E, Bürgin W, Lang N P. Effect of implant design on survival and success rates of titanium oral implants: a 10-year prospective cohort study of the ITI Dental Implant System. Clin Oral Implants Res 2004; 15: 8-17.

18. Brägger U, Karoussis I, Persson R, Pjetursson B, Salvi G, Lang N. Technical and biological complications/failures with single crowns and fixed partial dentures on implants: a 10- year prospective cohort study. Clin Oral Implants Res 2005; 16 : 326-334.

19. Pjetursson BE, Asgeirsson AG, Zwahlen M, Sailer I. Improvements in implant dentistry over the last decade: comparison of survival and complication rates in older and newer publications. Int J Oral Maxillofac Implants 2014; 29(Suppl): 308-324.

20. Axelsson P, Nyström B, Lindhe J. The long-term effect of a plaque control program on tooth mortality, caries and peri- odontal disease in adults. Results after 30 years of mainte- nance. J Clin Periodontol 2004; 31: 749-757.

21. Fransson C, Lekholm U, Jemt T, Berglundh T. Prevalence of subjects with progressive bone loss at implants. Clin Oral Implants Res 2005; 16: 440-446.

22. Nyman S, Lindhe J. Examination of patients with periodontal disease. In: Lindhe J, ed. Textbook of clinical periodontology. Copenhagen: Munksgaard, 1989; 310-322.

23. Edelhoff $D$, Sorensen JA. Tooth structure removal associated with various preparation designs for posterior teeth. Int J Periodontics Restorative Dent 2002; 22: 241-249.

24. Edelhoff $D$, Sorensen JA. Tooth structure removal associated with various preparation designs for anterior teeth. J Prosthet Dent 2002; 87: 503-509.

25. Hull PS, Worthington HV, Clerehugh V, Tsirba R, Davies RM, Clarkson JE. The reasons for tooth extractions in adults and their validation. J Dent 1997; 25: 233-237.

26. Pjetursson BE, Helbling C, Weber HP, et al. Peri-implantitis susceptibility as it relates to periodontal therapy and supportive care. Clin Oral Implants Res 2012; 23: 888894. 
English Summary

\title{
Are dental implants better than natural teeth?
}

\author{
BJARNI ELVAR PJETURSSON, DDS, DR. MED. DENT, MAS, PHD, PROFESSOR AND HEAD OF RESTORATIVE \\ DENTISTRY, FACULTY OF ODONTOLOGY, UNIVERSITY OF ICELAND. \\ KRISTIN HEIMISDOTTIR, DDS, ASSISTANT PROFESSOR, HEAD OF ORTHODONTICS, FACULTY OF ODONTOLOGY, \\ UNIVERSITY OF ICELAND.
}

ICELANDIC DENTAL JOURNAL 2019; 37: 38-45

doi: 10.33112/tann.37.1.4

There is vast amount of information on dental treatment on the internet, often indicating excellent survival and success rates of different types of implant-supported fixed dental prostheses. However, there is much less information regarding survival and success rates of the natural teeth - sometimes leaving the reader a bit confused, if natural teeth are as good as dental implants. The present article emphasizes the importance of making an evidence-based treatment plan with the best possible outcome for the patient. Dental implants and implant-supported restorations are an excellent treatment modality, but it must always be kept in mind that it is associated with a risk of biological and technical complications. Implants are supposed to replace missing teeth - they are not supposed to replace teeth.

Keywords: implant survival, tooth survival, success, treatment planning, risk analysis.

Correspondence: Bjarni Elvar Pjetursson, e-mail: bep@hi.is 